Check for updates

Cite this: RSC Adv., 2017, 7, 42685

Received 20th July 2017

Accepted 21st August 2017

DOI: $10.1039 / c 7 r a 08005 k$

rsc.li/rsc-advances

\section{The study of perylene diimide-amino acid derivatives for the fluorescence detection of anions $\dagger$}

\author{
Chao-yuan Chen, Ke Wang, Lei-lei Gu and Hui Li (DD * \\ Four types of perylene diimide-amino acid derivatives $\left(\mathrm{H}_{2}\right.$ PDIAla, $\mathrm{H}_{2}$ PDIGlu, $\mathrm{H}_{2}$ PDIPhe, $\mathrm{H}_{2}$ PDITyr $)$ were \\ chosen to interact with anions. The UV-vis, fluorescence (in DMF solution) and NMR spectra in DMSO- $d_{6}$ \\ solution were studied. The results indicated that the four types of derivatives exhibit specific selectivity \\ and high sensitivity for $\mathrm{F}^{-}$and $\mathrm{OH}^{-}$ions. The $\mathrm{NMR}$ titrations of the derivatives with $\mathrm{F}^{-}$and $\mathrm{OH}^{-}$ions \\ confirmed the synergetic effect of hydrogen bonding and anion $-\pi$ interaction between the derivatives \\ and the anions $\left(\mathrm{F}^{-}, \mathrm{OH}^{-}\right)$. In addition, we made a simple test-paper to develop its potential applications.
}

\section{Introduction}

Hydrogen bonding is the most important and widespread intermolecular interaction. ${ }^{1}$ The scientific branches involving the importance of hydrogen bonding are very diverse, including inorganic and organic chemistry, supramolecular chemistry, biochemistry, and medicine. ${ }^{2}$ It is operative in determining molecular conformation, molecular aggregation, and the function of a vast number of chemical systems ranging from inorganic to biological and is emerging as a powerful tool in the design of functional materials. ${ }^{3}$ In recent years, receptors using hydrogen bonding have been extensively developed, and a variety of functions have been investigated, including recognition, sensing, catalysis, and carrier-mediated transport across membranes. ${ }^{4}$

Perylene Diimide (PDI) is a valuable functional dye, which has numerous potential properties such as unique lightharvesting, redox properties, high chemical persistency, thermal durability, and outstanding optical and electronic properties. It has been applied as pigments, in fluorescent detectors, and semiconductors in organic electronics and photovoltaics. $^{5}$

Anions are ubiquitous in environment and food samples and play an important role in numerous types of biological and medicinal processes. ${ }^{6}$ The design and development of synthetic receptors to recognize specific anions selectively had received more and more attention in recent years. ${ }^{7}$ Using PDI derivatives

Key Laboratory of Clusters Science of Ministry of Education, Beijing Key Laboratory of Photoelectronic/Electrophotonic Conversion Materials, School of Chemistry and Chemical Engineering, Beijing Institute of Technology, Beijing, 100081, China. E-mail: lihui@bit.edu.cn

$\dagger$ Electronic supplementary information (ESI) available: Spectra (IR, UV-vis, ${ }^{1} \mathrm{H}$ NMR, ${ }^{13} \mathrm{C}$ NMR, ESI-MS, fluorescence life time), or other electronic format. See DOI: $10.1039 / \mathrm{c} 7 \mathrm{ra0} 08005 \mathrm{k}$ to detect anions became a developing trend of research. Sourav Saha and co-workers used aliphatic chain modified PDI to detect $\mathrm{F}^{-}$and $\mathrm{OH}^{-}$, which demonstrated anion- $\pi$ electronic interactions from $\mathrm{OH}^{-}$and $\mathrm{F}^{-}$ions to PDI in aprotic solvents. ${ }^{8}$ On the other hand, a type of PDI derivative incorporated with functional groups of chloroacetamide $\left(-\mathrm{NH}-(\mathrm{C}=\mathrm{O})-\mathrm{CH}_{2}-\mathrm{Cl}\right)$ has been studied for fluoride ion detection. ${ }^{9}$ It possesses a specific selectivity and high sensitivity for fluoride ion $\left(\mathrm{F}^{-}\right)$ among the halogen anions. The recognition was attributed to the intermolecular proton transfer between a hydrogen atom on the amide of the sensor and the fluoride anion. Based on this result, a new colorimetric and ratiometric fluorescent sensor for naked-eye detection of fluoride ion based on PDI-amide derivatives has been designed and synthesized. ${ }^{\mathbf{1 0}}$ In consideration of the important effect of hydrogen bonding, the PDI derivatives equipped with a - $\mathrm{COOH}$ group, such as amino acid, should form a strong hydrogen bonding. However, there is no report of PDI-amino acid derivatives applied in detection of anions in literature. Amino acids are essential structural units and physiologically active substances of life and are environment friendly. The new material designed with amino acids has advantages of being green and safe, low price, easy to synthesize and so on.

Herein, we report the studies of PDI-amino acid derivatives $\left(\mathrm{H}_{2}\right.$ PDIAAs) as fluorescent sensors to detect anions, particularly halogen ions, in organic solvents. Four types of $\mathrm{H}_{2}$ PDIAAs have been selected, which are perylene diimides functionalized with L-alanine ( $\mathrm{H}_{2}$ PDIAla), L-glutamic acid ( $\mathrm{H}_{2}$ PDIGlu), L-phenylalanine ( $\left.\mathrm{H}_{2} \mathrm{PDIPhe}\right)$ and L-tyrosine ( $\left.\mathrm{H}_{2} \mathrm{PDITyr}\right)$ (Scheme 1$)$. A comparative study and discussion on their fluorescent properties have been provided explaining their interaction with halogen ions in DMF as $\mathrm{H}_{2}$ PDIAAs have good solubility and strong fluorescence in DMF only. This work applies the PDIamino acid derivatives on the fluorescent sensor to detect anions based on hydrogen bonding for the first time. 


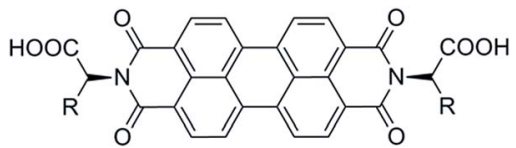

$\mathrm{R}=$

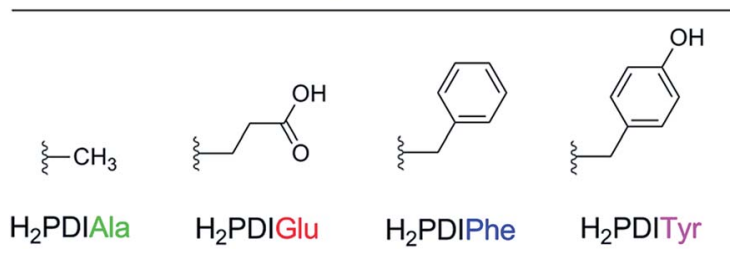

Scheme 1 Structural representations of PDI functionalized with L-alanine $\left(\mathrm{H}_{2}\right.$ PDIAla), L-glutamic acid $\left(\mathrm{H}_{2}\right.$ PDIGlu), L-phenylalanine $\left(\mathrm{H}_{2}\right.$ PDIPhe) and L-tyrosine $\left(\mathrm{H}_{2} \mathrm{PDITyr}\right)$.

\section{Experimental}

\section{Materials and measurements}

All materials were reagent grade and obtained from commercial sources and used without further purification. IR spectra were recorded on a Nicolet-360 FT-IR spectrophotometer using $\mathrm{KBr}$ pellets. Absorbance spectra were obtained with a Persee TU-1950 spectrophotometer; the luminescent spectra were recorded at room temperature on Hitachi F-7000 FL spectrophotometer with a xenon arc lamp ashen light source spectra, with the pass width of $E_{\mathrm{x}}=2.5 \mathrm{~nm}, E_{\mathrm{m}}=2.5 \mathrm{~nm}$. NMR spectra were recorded on a Bruker $400 \mathrm{MHz}$, and DMSO- $d_{6}$ was used as the solvent, with TMS as the internal standard.

\section{General procedure for $\mathrm{H}_{2}$ PDIAAs}

The four types of $\mathrm{H}_{2}$ PDIAAs have been synthesized according to the method reported in literature. ${ }^{11}$ Furthermore, 3,4,9,10-perylene tetracarboxylic acid dianhydride $(0.500 \mathrm{~g}, 1.28 \mathrm{mmol})$ in DMSO $(50 \mathrm{~mL})$ was heated at $100{ }^{\circ} \mathrm{C}$ with stirring. The amino acids, L-alanine ( $\mathrm{H}_{2}$ PDIAla) $(0.341 \mathrm{~g}, 3.83 \mathrm{mmol})$, L-glutamic acid ( $\mathrm{H}_{2}$ PDIGlu) (0.563 g, $\left.3.83 \mathrm{mmol}\right)$, L-phenylalanine ( $\mathrm{H}_{2}$ PDIPhe) (0.632 g, $3.83 \mathrm{mmol}$ ) or L-tyrosine ( $\left.\mathrm{H}_{2} \mathrm{PDITyr}\right)(0.594 \mathrm{~g}$, $3.83 \mathrm{mmol}$ ) was dissolved in $2 \mathrm{M} \mathrm{KOH} \mathrm{aq.}(2.5 \mathrm{~mL})$. The solution of potassium amino acid salt was added to the mixture. The mixture was stirred for 3 hours at $100{ }^{\circ} \mathrm{C}$ before cooling to the room temperature with the formation of a precipitate, which was recovered by filtration and recrystallized from hot water and acetone to yield the dipotassium salt $\mathrm{K}_{2}$ PDIAAs. Moreover, $2 \mathrm{M}$ $\mathrm{HCl}$ aq. ( $5 \mathrm{~mL}$ ) was added, recovered by filtration, and washed extensively with water before being dried in vacuo (NMR, ESI-MS, IR for $\mathrm{H}_{2}$ PDIAAs in Fig. S1-S16 $\dagger$ ). $N, N^{\prime}$-Bis-(L-alanine)3,4,9,10-perylene tetracarboxylic diimide ( $\mathrm{H}_{2}$ PDIAla). Yields: $\mathrm{H}_{2}$ PDIAla (0.512 g, 75\%). ${ }^{1} \mathrm{H}$ NMR (400 MHz, DMSO- $d_{6}$ ): $\delta 7.88$ $(\mathrm{d}, J=7.7 \mathrm{~Hz}, 4 \mathrm{H}), 7.75$ (d, $J=8.1 \mathrm{~Hz}, 4 \mathrm{H}), 5.52$ (dd, $J=13.9$, $6.8 \mathrm{~Hz}, 2 \mathrm{H}), 1.67$ (d, $J=7.0 \mathrm{~Hz}, 6 \mathrm{H}) .{ }^{13} \mathrm{C}$ NMR (100 MHz, DMSO$\left.d_{6}\right): \delta 172.2,162.2,133.2,130.8,127.9,124.4,123.5,122.0,49.5$, 15.4. IR (film): $\nu=1747,1695,1653,1592,1437,1343,1256,974$, 809, $747 \mathrm{~cm}^{-1}$. ESI-MS: $m / z=535[\mathrm{M}+\mathrm{H}]^{+} . N, N^{\prime}$-Bis-(L-glutamic acid)-3,4,9,10-perylene tetracarboxylic diimide ( $\left.\mathrm{H}_{2} \mathrm{PDIGlu}\right)$. Yields: $\mathrm{H}_{2}$ PDIGlu $(0.611 \mathrm{~g}, 73 \%) .{ }^{1} \mathrm{H}$ NMR $\left(400 \mathrm{MHz}, \mathrm{DMSO}-d_{6}\right)$ : $\delta 12.5$ (br s, 4H), 8.43-7.94 (m, 8H), 5.66-5.53 (m, 2H), 2.61-2.47 (m, 4H), 2.46-2.25 (m, 4H). ${ }^{13} \mathrm{C}$ NMR (100 MHz, DMSO- $\left.d_{6}\right)$ : $\delta$ 174.0, 170.9, 162.3, 133.1, 130.7, 128.0, 124.6, 123.1, 121.8, 52.7, 30.8, 23.9. IR (film): $\nu=1751,1697,1642,1591,1363,1255,1168$, 809, $747 \mathrm{~cm}^{-1}$. ESI-MS: $m / z=651[\mathrm{M}+\mathrm{H}]^{+} . N, N^{\prime}$-Bis-(L-phenylalanine)-3,4,9,10-perylene tetracarboxylic diimide ( $\left.\mathrm{H}_{2} \mathrm{PDIPhe}\right)$. Yields: $\mathrm{H}_{2}$ PDIPhe $(0.652 \mathrm{~g}, 74 \%) .{ }^{1} \mathrm{H}$ NMR (400 MHz, DMSO- $d_{6}$ ):

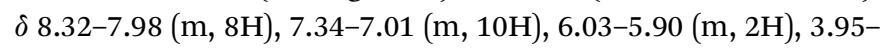
$3.18(\mathrm{~m}, 4 \mathrm{H}) .{ }^{13} \mathrm{C}$ NMR (100 MHz, DMSO- $\left.d_{6}\right): \delta 170.6,162.18$, 137.9, 133.8, 131.1, 129.1, 128.2, 128.1, 126.4, 125.2, 123.6, 121.7, 54.0, 34.3. IR (film): $\nu=1736,1698,1659,1592,1435,1365,1254$, 1168, 810, $747 \mathrm{~cm}^{-1}$. ESI-MS: $m / z=687[\mathrm{M}+\mathrm{H}]^{+} \cdot N, N^{\prime}$-Bis(L-tyrosine)-3,4,9,10-perlene tetracarboxylic diimide ( $\left.\mathrm{H}_{2} \mathrm{PDITyr}\right)$. Yields: $\mathrm{H}_{2}$ PDITyr (0.593 g, 70\%). ${ }^{1} \mathrm{H}$ NMR (400 MHz, DMSO- $\left.d_{6}\right)$ : o 8.29-7.75 (m, 8H), 7.15-7.97 (m, 4H), 6.64-6.51 (m, 4H), 5.99$5.85(\mathrm{~m}, 2 \mathrm{H}), 3.58-3.46(\mathrm{~m}, 2 \mathrm{H}), 3.44-3.31$ (m, 2H). ${ }^{13} \mathrm{C}$ NMR (100 MHz, DMSO- $\left.d_{6}\right): \delta 170.8,162.1,155.9,133.4,130.9,130.1$, 127.9, 127.8, 124.9, 123.2, 121.6, 115.0, 54.1, 33.4. IR (film): $\nu=$ 1692, 1649, 1592, 14 434, 1402, 1367, 1253, 1009, 825, $745 \mathrm{~cm}^{-1}$. ESI-MS: $m / z=719[\mathrm{M}+\mathrm{H}]^{+}$.

\section{Preparation of solutions for absorbance and fluorescence detections}

The stock solution of $\mathrm{H}_{2}$ PDIAAs was prepared in DMF $\left(1 \times 10^{-5}\right.$ $\mathrm{M})$, and each inorganic salt $\left(\mathrm{NaH}_{2} \mathrm{PO}_{4}, \mathrm{Na}_{2} \mathrm{HPO}_{4}, \mathrm{Na}_{3} \mathrm{PO}_{4}\right.$, $\mathrm{Na}_{4} \mathrm{P}_{2} \mathrm{O}_{7}(\mathrm{PPi}), \mathrm{NaNO}_{3}, \mathrm{NaHCO}_{3}, \mathrm{Na}_{2} \mathrm{CO}_{3}, \mathrm{NaHSO}_{4}, \mathrm{Na}_{2} \mathrm{SO}_{4}$, tetrabutylammonium fluoride (TBAF), tetrabutylammonium chloride (TBACl), tetrabutylammonium bromide (TBABr), tetrabutylammonium iodide (TBAI), tetrabutylammonium hydroxide $(\mathrm{TBAOH}))$ was dissolved in DMF $\left(1.5 \times 10^{-2} \mathrm{M}\right)$.

\section{Test-paper measurement}

The silica gel plate $\left(2 \times 1.5 \mathrm{~cm}^{2}\right)$ was immersed in the DMF solution of $\mathrm{H}_{2}$ PDIAla $\left(1 \times 10^{-5} \mathrm{M}\right)$ by soaking half of it and then dried using the blower. The letters (BIT) were written both in the upper and lower panels with the TBAF solution and then put under the visible light and UV light $(\lambda=365 \mathrm{~nm})$.

\section{Fluorescence lifetime decay}

Fluorescence decay lifetime was measured using a timecorrelated single photon counting instrument. Only freshly prepared solutions were used for the spectroscopic study, and all experiments were carried out at room temperature $(298 \mathrm{~K})$. Fluorescence lifetime was measured using Fluorolog-Tau-3 picosecond level fluorescence spectroscopy.

\section{Results and discussion}

\section{UV-vis spectra}

The UV-vis spectra of $\mathrm{H}_{2}$ PDIAAs show the typical features of perylene absorption with three peaks. ${ }^{12}$ The interactions of $\mathrm{H}_{2}$ PDIAAs with different anions were studied by UV-vis absorption spectroscopy, in which there was found to be an obvious change in the presence of $\mathrm{F}^{-}$and $\mathrm{OH}^{-}$ions among $\mathrm{Cl}^{-}$, $\mathrm{Br}^{-}, \mathrm{I}^{-}, \mathrm{H}_{2} \mathrm{PO}_{4}{ }^{-}, \mathrm{HPO}_{4}{ }^{2-}, \mathrm{PO}_{4}{ }^{3-}, \mathrm{PPi}, \mathrm{NO}_{3}{ }^{-}, \mathrm{HCO}_{3}{ }^{-}, \mathrm{CO}_{3}{ }^{2-}$, $\mathrm{HSO}_{4}{ }^{-}$, and $\mathrm{SO}_{4}{ }^{2-}$ ions (Fig. S17†). Fig. 1 exhibits the results of 

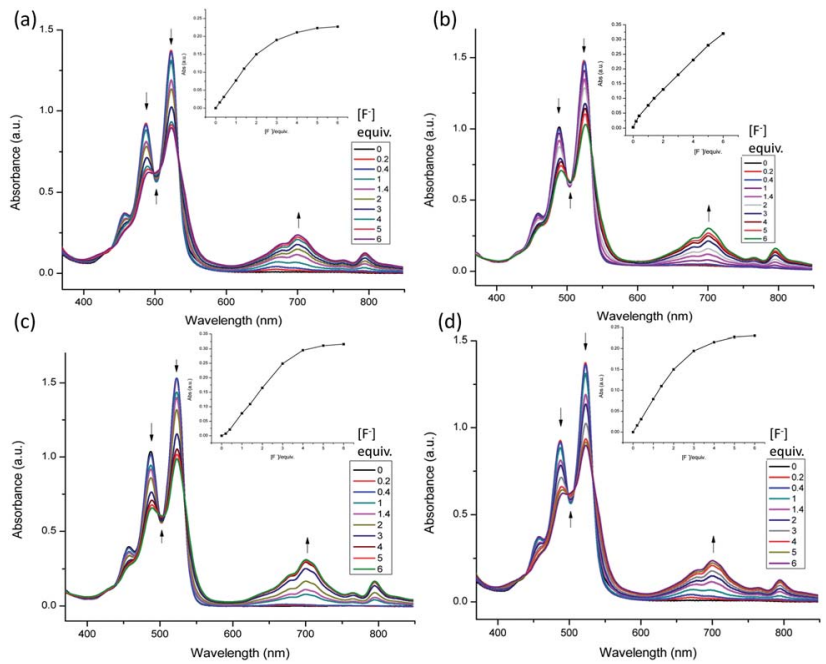

Fig. 1 UV-vis titration of $\mathrm{H}_{2}$ PDIAAs with TBAF in DMF $\left(1 \times 10^{-5} \mathrm{M}\right)$, (a) $\mathrm{H}_{2}$ PDIAla, (b) $\mathrm{H}_{2}$ PDIGlu, (c) $\mathrm{H}_{2}$ PDIPhe, (d) $\mathrm{H}_{2}$ PDITyr. Inset: UV absorbance intensity at $700 \mathrm{~nm} v \mathrm{~s}$. concentration of $\mathrm{F}^{-}$ion.

UV-vis titration by adding TBAF into $\mathrm{H}_{2}$ PDIAAs in DMF solution. Clearly, the typical absorption peaks red-shifted, and a new peak appeared around $700 \mathrm{~nm}$. With the same condition, the UV-vis spectrometric titrations of $\mathrm{H}_{2}$ PDIAAs with other anions did not show any significant change. Moreover, the inset pictures in Fig. 1 suggest that it has a good linearity between the absorbance at $700 \mathrm{~nm}$ with the concentrations of $\mathrm{F}^{-}$from 0.2 eq. to 6 eq., which indicates that $\mathrm{H}_{2}$ PDIAla can detect $\mathrm{F}^{-}$quantitatively. The linear equation was found to be $y=0.0152 x+0.0008(R=0.9991)$, where " $y$ " is the absorbance at $700 \mathrm{~nm}$ measured at a given $\mathrm{F}^{-}$concentration, and " $x$ " represents the equivalent of $\mathrm{F}^{-}$added. When the concentration of $\mathrm{F}^{-}$was less than 1 equivalent of PDI, there was no large absorbance around $700 \mathrm{~nm}$, and the absorbance appeared after the concentration of $\mathrm{F}^{-}$was more than 1 equivalent of PDI. The same trend in the detection was found using $\mathrm{H}_{2}$ PDIPhe and $\mathrm{H}_{2}$ PDITyr (Fig. $1 \mathrm{c}$ and $\mathrm{d}$ inset), but $\mathrm{H}_{2}$ PDIGlu showed a different tendency in detection of $\mathrm{F}^{-}$because it contains four carboxyl groups and has a capacity to accept more $\mathrm{F}^{-}$ions (Fig. $1 \mathrm{~b}$ inset, $\mathrm{S} 18 \dagger$ ). The $\mathrm{OH}^{-}$ion shows similar phenomenon with $\mathrm{F}^{-}$ion when it interacts with $\mathrm{H}_{2}$ PDIAAs (Fig. S19†).

\section{Fluorescent properties}

The interactions between $\mathrm{H}_{2}$ PDIAAs and various anions were studied by fluorescence spectra. There was an obvious change in fluorescence spectra of $\mathrm{H}_{2}$ PDIAAs in the presence of $\mathrm{F}^{-}$and $\mathrm{OH}^{-}$ions as shown in Fig. S20. $\dagger$ Furthermore, fluorescence titration by adding standard solution of TBAF in DMF has been applied in investigation of $\mathrm{H}_{2}$ PDIAAs interacting with $\mathrm{F}^{-}$and $\mathrm{OH}^{-}$ions (Fig. 2 and S21 $\dagger$ ). The four compounds have different fluorescence intensity from the strongest 7500 (a.u., $\mathrm{H}_{2}$ PDIPhe) to the lowest 1500 (a.u., $\mathrm{H}_{2}$ PDITyr), which may be related to the different substitutes on the branched chain of the four compounds. In order to understand the fluorescence behavior of $\mathrm{H}_{2}$ PDIAAs in solution better, we measured the fluorescence lifetime of these four compounds in DMF and calculated the
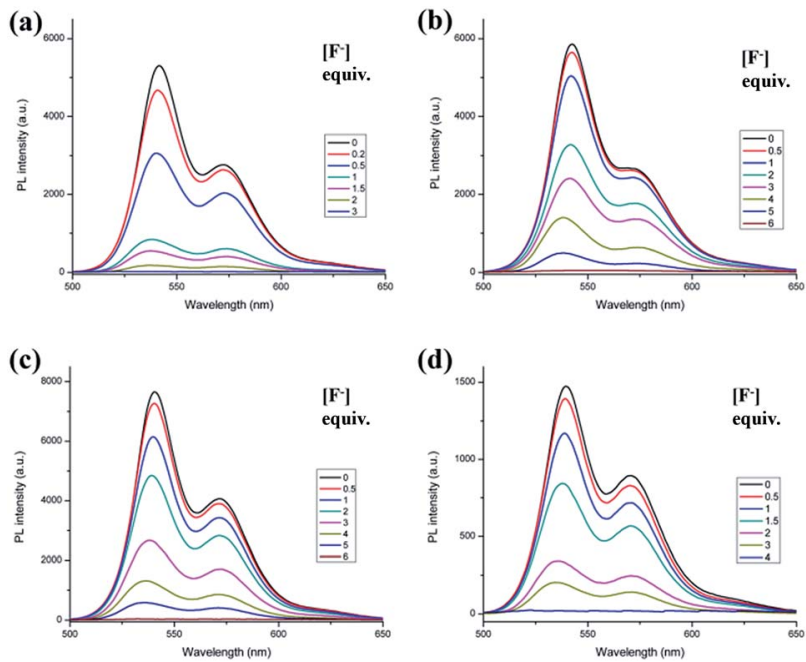

Fig. 2 Fluorescence emission of $\mathrm{H}_{2}$ PDIAAs with TBAF titration in DMF $\left(1 \times 10^{-5}\right.$ M) $\left(\lambda_{\text {ex }}=525 \mathrm{~nm}\right)$, (a) $\mathrm{H}_{2}$ PDIAla, (b) $\mathrm{H}_{2}$ PDIGlu, (c) $\mathrm{H}_{2}$ PDIPhe and (d) $\mathrm{H}_{2}$ PDITyr.

theoretical quantum yield, shown in Table 1, in which the quantum yield of $\mathrm{H}_{2}$ PDIPhe in the four compounds is the largest one, and $\mathrm{H}_{2}$ PDITyr is the lowest. As a general rule, the fluorescence intensity is proportional to the fluorescence quantum yield. Therefore, this result is consistent with the fluorescence intensity measured with the same conditions, as shown in Fig. 2. The fluorescence lifetime of $\mathrm{H}_{2}$ PDITyr is longer than that of the other three $\mathrm{H}_{2}$ PDIAAs.

As shown in Fig. 2, the $\mathrm{H}_{2}$ PDIAla has been found to have sensitivity higher than that of the other three compounds. The $\mathrm{OH}^{-}$ion also has similar phenomenon with the interaction of $\mathrm{H}_{2}$ PDIAAs (Fig. S21†), and fluorescence quenching can also be observed.

\section{Fluorescent detectors for anions}

Besides the UV-vis and fluorescent spectra, the selectivity of $\mathrm{H}_{2}$ PDIAAs to $\mathrm{F}^{-}$and $\mathrm{OH}^{-}$ions can also be well identified by the naked eye with colorimetric change (Fig. 3). The interactions of $\mathrm{H}_{2} \mathrm{PDIAla}$ probe with various anions $\left(\mathrm{H}_{2} \mathrm{PO}_{4}{ }^{-}, \mathrm{HPO}_{4}{ }^{2-}, \mathrm{PO}_{4}{ }^{3-}\right.$, $\mathrm{PPi}, \mathrm{NO}_{3}{ }^{-}, \mathrm{HCO}_{3}{ }^{-}, \mathrm{CO}_{3}{ }^{2-}, \mathrm{HSO}_{4}{ }^{-}, \mathrm{SO}_{4}{ }^{2-}, \mathrm{Cl}^{-}, \mathrm{Br}^{-}, \mathrm{I}^{-}$) compared with $\mathrm{F}^{-}$were studied. Upon adding various anions to the blank solution of $\mathrm{H}_{2}$ PDIAla, no appreciable color change was noticed under the visible light and UV light (Fig. 3a). Therefore, it was inferred that there were no interactions between $\mathrm{H}_{2}$ PDIAla and various anions mentioned.

Table 1 The quantum yield $\left(\Phi_{\mathrm{F}}\right)$ and lifetime of $\mathrm{H}_{2}$ PDIAAs in DMF solution $\left(1 \times 10^{-5} \mathrm{M}\right)$

\begin{tabular}{lllll}
\hline & $\mathrm{H}_{2}$ PDIAla & $\mathrm{H}_{2}$ PDIGlu & $\mathrm{H}_{2}$ PDIPhe & $\mathrm{H}_{2}$ PDITyr \\
\hline${\text { Quantum yield }\left(\Phi_{\mathrm{F}}\right)^{a}}^{a}$ & 0.27 & 0.36 & 0.66 & 0.11 \\
$\tau(\mathrm{ns})^{b}$ & 4.51 & 4.65 & 4.54 & 5.06
\end{tabular}

${ }^{a}$ The quantum yield $\left(\Phi_{\mathrm{F}}\right)$ was measured relative to the fluorescein solution in $0.1 \mathrm{M} \mathrm{NaOH}\left(\Phi_{\mathrm{F}}=0.79\right) \cdot{ }^{13}{ }^{b}$ Fluorescence lifetime values $\left(\lambda_{\mathrm{em}}=541,572 \mathrm{~nm}\right)$. 


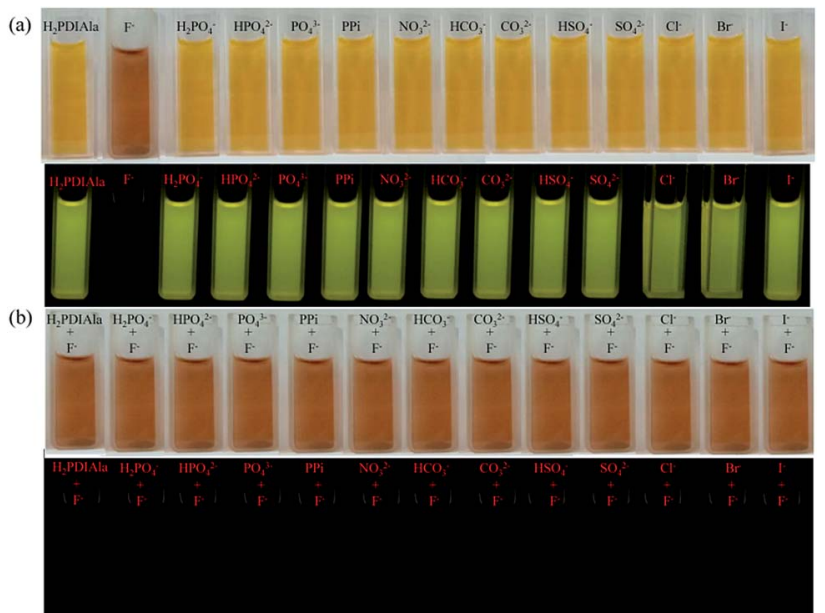

Fig. 3 (a) The photographs of colorimetric identification by naked eye and fluorescence emission $\left(\lambda=365 \mathrm{~nm}\right.$ ) of $\mathrm{H}_{2}$ PDIAla with various ions ( 6 eq., each). (b) The photographs of colorimetric identification by naked eye and fluorescence emission $(\lambda=365 \mathrm{~nm})$ of $\mathrm{H}_{2}$ PDIAla $-\mathrm{F}^{-}$ion with various ions ( 6 eq., each).

Furthermore, with the addition of $\mathrm{F}^{-}$ion to the above solution, the color of both blank solution and that containing various anion's solution changed from yellow to brown as observed by the naked eye and fluorescence quenching under UV light (Fig. 3b). Clearly, the $\mathrm{H}_{2}$ PDIAla can be a fluorescent probe for $\mathrm{F}^{-}$ ion even with the existence of various other anions. Moreover, the detections by $\mathrm{H}_{2}$ PDIGlu, $\mathrm{H}_{2}$ PDIPhe and $\mathrm{H}_{2}$ PDITyr were almost the same except for the difference of color changes with $\mathrm{H}_{2}$ PDIGlu from yellow to purple, $\mathrm{H}_{2}$ PDIPhe from yellow to brick red, and $\mathrm{H}_{2}$ PDITyr from jacinth to brown (Fig. S22-S24 $\dagger$ ). The detection for $\mathrm{OH}^{-}$ion by the fluorescent probe $\mathrm{H}_{2}$ PDIAAs has been processed, and a similar phenomenon was observed with fluorescence quenching and a color change could be observed by the naked eye (Fig. S25-S28†).

In order to improve the convenience and rapidity of $\mathrm{F}^{-}$ion detection out of the laboratory, we made a simple test-paper, which used the existing $\mathrm{H}_{2}$ PDIAA solution with silica gel plate. By soaking half of the silica gel plate in the solution and drying, the letters "BIT" were written in both the upper and lower panels with the TBAF solution. There was a significant difference between the soaked part and the control part. The letters "BIT" could clearly be observed under the visible light and UV light, but there was nothing on the control part (Fig. 4). It suggests that this method can be used to detect $\mathrm{F}^{-}$ion conveniently and practically.

\section{Mechanism of the fluorescent detectors}

The NMR titration experiment is very useful in studying the mechanism of $\mathrm{H}_{2}$ PDIAAs to detect anions in solutions (Fig. 5). According to our NMR titration experiment, when the addition of $\mathrm{F}^{-}$was equal or less than 1 equivalent of PDI, the signal of core structure protons always existed, whereas the signal of carboxylic acid moved to a low magnetic field and became broader. On the other hand, the signal of core structure protons gradually disappeared with the increasing of $\mathrm{F}^{-}$concentration

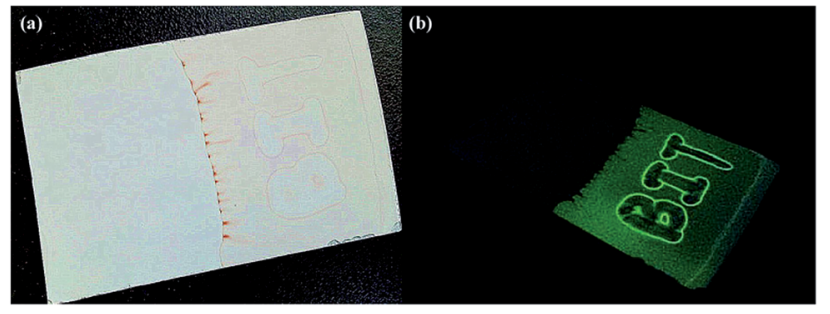

Fig. 4 Photographs of test-paper of $\mathrm{H}_{2}$ PDIAla solution in DMF $(1 \times$ $\left.10^{-5} \mathrm{M}\right)$ of TBAF. (a) Visible light of the test-paper, (b) UV light $(\lambda=$ $365 \mathrm{~nm}$ ) of the test-paper.

after more than 1 equivalent of PDI. The results indicated that when the concentration of $\mathrm{F}^{-}$was equal or less than 1 equivalent of PDI, the association between $\mathrm{H}_{2}$ PDIAAs and $\mathrm{F}^{-}$could be through the hydrogen bonding between the $\mathrm{H}^{+}$of carboxylic acid (-COOH proton) and $\mathrm{F}^{-}\left(\mathrm{COO}-\mathrm{H}^{\cdots} \cdots \mathrm{F}^{-}\right)$. The formation of hydrogen bonding followed by deprotonation of the $-\mathrm{COOH}$ fragment could reduce the electron density on the carboxylic moiety, which decreases the electron density of the core benzene ring of PDI, deshielding the corresponding protons and moving them to a low magnetic field. ${ }^{14}$ Clearly, when the concentration of $\mathrm{F}^{-}$is more than 1 equivalent of PDI, there is an interaction between core structure and $\mathrm{F}^{-}$. Moreover, UV-vis titration experiments indicated that the PDI anion radicals were generated at high concentration of $\mathrm{F}^{-}$. These results indicated that anion- $\pi$ interaction may play the leading role in the association between $\mathrm{H}_{2}$ PDIAAs and $\mathrm{F}^{-}$at high concentrations of $\mathrm{F}^{-}$. A similar phenomenon for $\mathrm{OH}^{-}$ion was observed (Fig. S32 $\dagger$ ). Based on the above observations and inferences, the synergetic effect of hydrogen bonding and anion- $\pi$ interaction in the fluorescent detection of $\mathrm{H}_{2}$ PDIAAs could be proposed

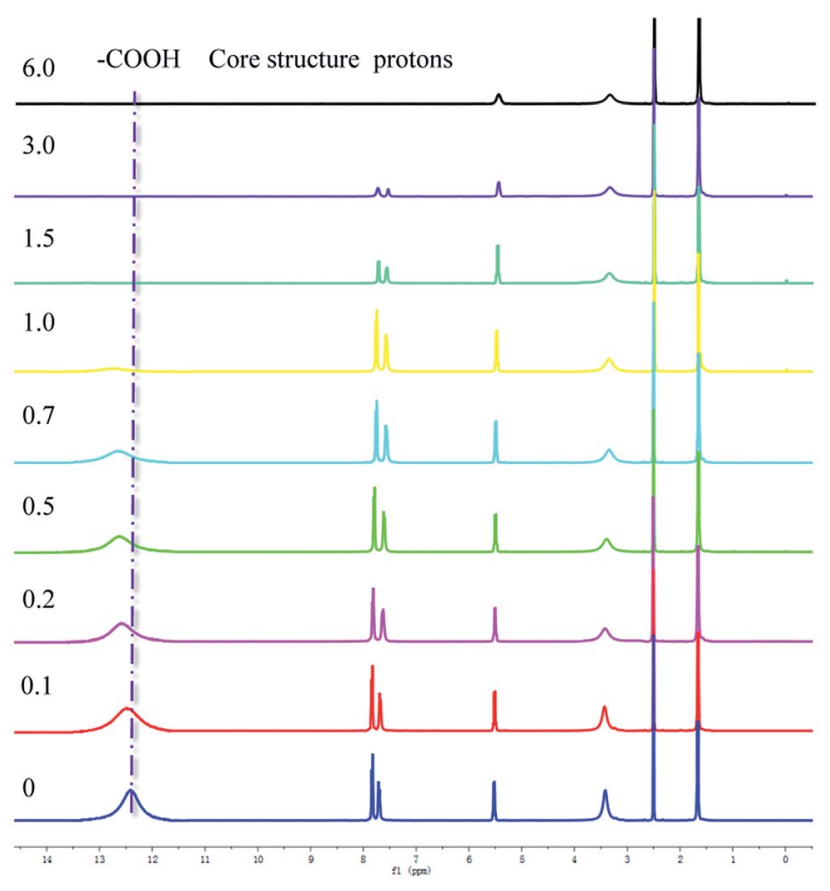

Fig. 5 The ${ }^{1} \mathrm{H}$ NMR titrations of $\mathrm{H}_{2}$ PDIAla with TBAF in DMSO- $d_{6}$. 


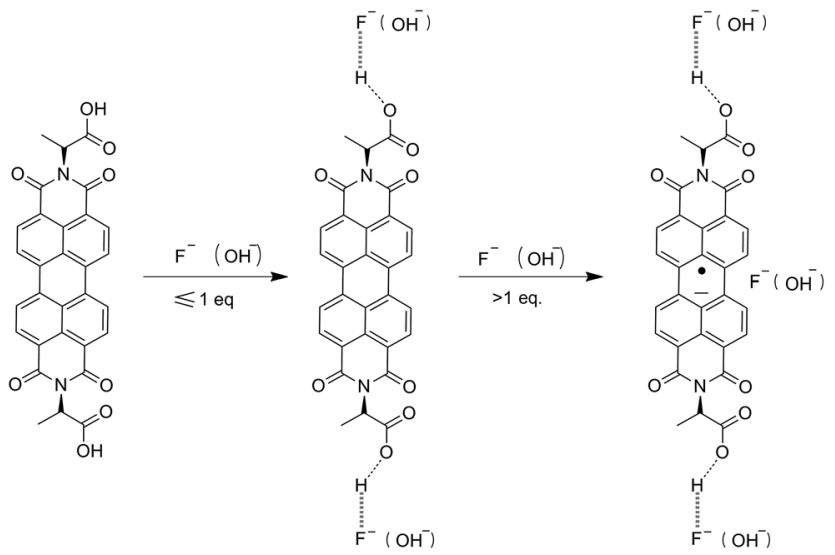

Scheme 2 Proposed mechanism of $\mathrm{H}_{2}$ PDIAA fluorescent probe to detect fluoride and hydroxide ions.

and, the mechanism of fluorescent detection of $\mathrm{H}_{2}$ PDIAAs towards anions can be inferred to be a synergetic effect (Scheme 2). To the best of our knowledge, this is the first report of PDI-amino acid derivatives as fluorescent probes to detect anions.

\section{Conclusion}

In summary, we have explored and discussed the fluorescent detection of anions using four types of PDI-amino acids derivatives. The result indicates that they are sensitive to $\mathrm{F}^{-}$and $\mathrm{OH}^{-}$ ions in DMF solution with an obvious color change and fluorescence quenching in a short time. The detecting mechanism has been proposed according to the molecular structures and NMR titrations. In addition, we made a simple test-paper to develop its potential applications. These results constitute a promising platform for the exploitation and applications of $\mathrm{H}_{2}$ PDIAAs as fluorescent probes, which are induced by the synergetic effect of hydrogen bonding and anion $-\pi$ interaction, and laid a solid foundation for the PDI's development for fluorescent detectors.

\section{Conflicts of interest}

There are no conflicts to declare.

\section{Acknowledgements}

This work was financially supported by the National Natural Science Foundation of China (no. 21471017).

\section{References}

1 S. Thomas, Angew. Chem., Int. Ed., 2002, 41, 48-76.

2 (a) E. E. Chufan, K. Kapoor and S. V. Ambudkar, Biochem. Pharmacol., 2016, 101, 40-53; (b) S. J. Yi, J. H. Kim, Y. J. Cho, J. Lee, T. S. Choi, D. W. Cho, C. Pac, W. S. Han, H. J. Son and S. O. Kang, Inorg. Chem., 2016, 55, 33243331; (c) J. W. Li, Y. F. Wang, J. F. Chen, Z. J. Liu, Ad. Bax and L. S. Yao, J. Am. Chem. Soc., 2016, 138, 1824-1827.
3 (a) Z. Y. Ma, Z. J. Wang, X. Meng, Z. M. Ma, Z. J. Xu, Y. G. Ma and X. R. Jia, Angew. Chem., Int. Ed., 2016, 55, 519-522; (b) M. Maschke, K. Merz, O. V. Shishkin, R. I. Zubatyuk and N. M. Nolte, Struct. Chem., 2016, 27, 377-387; (c) R. Stefanovic, M. Ludwig, G. B. Webber, R. Atkin and A. J. Page, Phys. Chem. Chem. Phys., 2017, 19, 3297-3306.

4 (a) M. Boiocchi, L. D. Boca, D. E. Gómez, L. Fabbrizzi, M. Licchelli and E. Monzani, J. Am. Chem. Soc., 2004, 126, 16507-16514; (b) H. J. Kim, M. J. Ajitha, Y. Lee, J. Ryu, J. Kim, Y. Lee, Y. Jung and S. Chang, J. Am. Chem. Soc., 2014, 136, 1132-1140; (c) P. A. Gale and C. Caltagirone, Chem. Soc. Rev., 2015, 44, 4212-4227; (d) D. D. Ford, D. Lehnherr, C. R. Kennedy and E. N. Jacobsen, ACS Catal., 2016, 6, 46164620; (e) A. Kaya, C. Onac, H. K. Alpoguz and A. Yilmaz, Chem. Eng. J., 2016, 283, 141-149.

5 (a) E. Kozma, W. Mróz and F. V. Monteleone, RSC Adv., 2016, 6, 61175-61179; (b) D. Görl, X. Zhang, V. Stepanenko and F. Würthner, Nat. Commun., 2015, 6, 7009; (c) J. P. Sun, A. D. Hendsbee, A. J. Dobson, G. C. Welch and I. G. Hill, Org. Electron., 2016, 35, 151-157.

6 (a) A. Dvivedi, S. Kumar and M. Ravikanth, Sens. Actuators, B, 2016, 24, 364-371; (b) K. Rajaguru, A. Mariappan, A. J. Beneto, G. Sivaraman, S. Muthusubramanian, A. Siva and N. Bhuvanesh, ChemistrySelect, 2016, 1, 1729-1736; (c) K. M. Vengaian, C. D. Britto, K. Sekar, G. Sivaraman and S. Singaravadivel, Spectrochim. Acta, Part B, 2016, 235, 232-240.

7 (a) T. Anand, G. Sivaraman, M. Iniya, A. Siva and D. Chellappa, Anal. Chim. Acta, 2015, 876, 1-8; (b) C. A. Swamy and P. Thilagar, Inorg. Chem., 2014, 53, 27762786; (c) B. Vidya, G. Sivaraman, R. V. Sumesh and D. Chellappa, ChemistrySelect, 2016, 1, 4024-4029.

8 (a) Y. Zhou, J. F. Zhang and J. Yoon, Chem. Rev., 2014, 114, 5511-5571; (b) S. Guha and S. Saha, J. Am. Chem. Soc., 2010, 132, 17674-17677; (c) F. S. Goodson, D. K. Panda, S. Ray, A. Mitra, S. Guha and S. Saha, Org. Biomol. Chem., 2013, 11, 4797-4803.

9 Y. S. Ma, Y. L. Zhao, F. X. Zhang, T. Y. Jiang, X. f. We, H. Shen, R. Wang and Z. Q. Shi, Spectrochim. Acta, Part B, 2017, 241, 735-743.

10 (a) Z. J. Chen, L. M. Wang, G. Zou, L. Zhang, G. J. Zhang, X. F. Cai and M. S. Teng, Dyes Pigm., 2012, 94, 410-415; (b) X. X. Chen, T. H. Leng, C. Y. Wang, Y. J. Shen and W. H. Zhu, Dyes Pigm., 2017, 14, 299-305.

11 S. A. Boer, C. S. Hawes and D. R. Turner, Chem. Commun., 2014, 50, 1125-1127.

12 (a) M. J. Farooqi, M. A. Penick, J. Burch, G. R. Negrete and L. Brancaleon, Spectrochim. Acta, Part A, 2016, 153, 124131; (b) E. Kozma, G. Grisci, W. Mróz, M. Catellani, A. Eckstein-Andicsovà, K. Pagano and F. Galeotti, Dyes Pigm., 2016, 125, 201-209.

13 (a) J. John, L. Thomas, A. Kurian and S. D. George, J. Lumin., 2016, 172, 39-46; (b) J. Daniel, A. G. Godin, M. Palayret, B. Lounis, L. Cognet and M. Blanchard Desce, J. Phys. D: Appl. Phys., 2016, 49, 084002.

14 J. H. Clark and J. M. Miller, Tetrahedron Lett., 1977, 18, 599602. 